\title{
Exotic Mite Family (Parholaspididae Evans, 1956) Introduced to Hungary: \\ First Record of Holaspina alstoni (Evans, 1956) from Hungarian Greenhouses (Acari: Mesostigmata)
}

\author{
J. KONTSCHÁN* and TÍMEA SZEDERJESI \\ Plant Protection Institute, Centre for Agricultural Research, Hungarian Academy of Sciences, \\ H-1525 Budapest, P.O. Box 102, Hungary
}

(Received: 9 September 2016; accepted: 16 September 2016)

\begin{abstract}
The species Holaspina alstoni (Evans, 1956) from the family Parholaspididae Evans, 1956 was collected in the soils of three different Hungarian greenhouses. This is the first record of this family, the genus and the species in Hungary. A new key to the European parholaspidid mites is presented.
\end{abstract}

Keywords: Acari, Mesostigmata, Parholaspididae, Holaspina alstoni, first record, greenhouse, Hungary.

The majority of the members of the order Mesostigmata is fast moving predatory mites occurring in all regions of the world and can be found in most types of habitats. The family Parholaspididae Evans, 1956 is one characteristic group which occurs in the Austral-Asian region, East and South-East Asia and America as well. We also know several occurrences of this group from Europe, but the species of this family were mentioned mainly from greenhouses (Karg, 1993) and only rarely from natural habitats (Moraza and Peña, 2006) or caves (Lindquist et al., 2009).

The investigation of the Hungarian greenhouses fauna denoted several interesting occurrences. Tropical, subtropical and Mediterranean exotic species were discovered (Korsós et al., 2002; Kontschán, 2004; Mahunka and Mahunka-Papp, 2007; Boros and Dózsa-Farkas, 2008) and new, previously not observed species were described from Hungarian greenhouses of the Hungarian botanical gardens in case of the enchytraeids (Boros and Dózsa-Farkas, 2008) and mites (Mahunka and Mahunka-Papp, 2007) as well. The Soil Zoology Collection of the Hungarian Natural History Museum is very rich in unsorted soil samples from all regions of Hungary. Besides the natural habitats numerous samples were collected from Hungarian botanical gardens and also from greenhouses. In the last years we checked the soil samples collected in greenhouses and we found a member from the Mesostigmata family Parholaspididae Evans, 1956 that hasn't previously

* Corresponding author; e-mail: kontschan.jeno@agrar.mta.hu 
been observed in Hungary. Now we present this result with the short description and new illustrations about the species Holaspina alstoni (Evans, 1956).

\section{Materials and Methods}

Specimens of these species were cleared in lactic acid, investigated on half covered deep slides, and illustrations were made with the aid of a drawing tube on a Leica 1000 scientific microscope. All specimens are stored in ethanol and deposited in the Hungarian Natural History Museum.

\section{Results}

Family Parholaspididae Evans, 1956

Short diagnosis: Holodorsal shield present and bearing 29 or more pairs of needle-like or spatuliform setae. Peritremes join strait to the stigmata anteriorly. Lateral accessory plates weakly developed or were absent in females. Corniculi long and swordshaped. Male with holoventral shield, male genital opening situated close to anterior margin of holoventral shield. Chelicerae of male with well-developed sperm transfer organ (after Krantz, 1960).

Type genus: Parholaspis Berlese, 1918

Distribution: Worldwide.

Genus Holaspina Berlese, 1916

Diagnosis: Genital, metasternal, ventrianal and peritrematal shields free, not fused with each other. First setae on j-row (j1) present and same in length as other dorsal setae.

Type species: Holaspina pulchella Berlese, 1916

Distribution: Worldwide, but the species of this genus are introduced by human transport into the temperate climate zone.

Holaspina alstoni (Evans, 1956)

Parholaspulus alstoni Evans, 1956: pp. 374-376. Figs 59-61.

Parholaspulus alstoni: Krantz, 1960: 417-418.; Petrova, 1977: 330. Fig. 232.; Ishikawa, 1980: 21-23.; Karg, 1993: 116.

Holaspina alstoni: Johnston, 1969: 273.; Datta and Bhattacharjee, 1989: 411.; Farrier and Hennessey, 1996: 105.; Lee and Lee, 1996: 25.; Kwon and Lee, 1999: 37.; Lee and Lee, 2000: 106.; Latifi et al., 2005: 193.; Kontschán et al., 2014: 20.

Material examined: One female. Hungary, Sopron, greenhouse of the University of Western-Hungary, 26.IX.2008., leg. J. Kontschán. One female. Hungary, Pécs, green- 
house of the University of Pécs, 26.VI.2006., leg. J. Kontschán. Eleven females. Hungary, Vácrátót, greenhouse of the National Botanic Garden of Institute of Ecology and Botanic, Centre for Ecological Researches, Hungarian Academy of Sciences, 22.III.2010., leg. G. Boros.

Short description: Holodorsal shield present and bearing 30 pairs of simple, needle-like setae (Fig. 1a). Presternal shield divided into seven pairs of oblong and narrow platelets. Sternal shield with three pairs of smooth and needle like setae and covered by reticulate sculptural pattern forming punctuation. One pair of lyriform fissures situated close to St1, and one pair of pores placed close to St2. St4 situated on small platelets. Genital shield with reticulate sculptural pattern and bearing one pair of needle-like genital setae. Surface of genital and ventrianal shields same as in sternal shield. Ventrianal shield subtriangular, anterior part with three pairs of needle-like setae, posterior part with anal opening and one pair of adanal and one postanal setae, all setae around anal opening smooth and needle-like (Fig. 1b). Epistome with three branches, two lateral branches apically pilose, central branch peaked and bearing one or more spine-like lateral processes on apical part. Margin of epistome among branches serrate (Fig. 1c). Corniculi sword-like, longer than palp trochanter (Fig. 1d). Chelicerae with two large teeth on movable digit and some smaller on fixed digit (Fig. 1e).

Notes: The shape of the ventrianal shield of the Hungarian specimens is similar to the illustration in Evans' (1956) original description. The illustration of Petrova (1977) about this species differs from Evans' (1956) original drawings: the ventrianal shield is wider and there are no differences in the length between the circum-anal and ventral setae. The Hungarian specimens have this difference between the circum-anal and ventral setae.

Distribution: The species Holaspina alstoni was described originally from the Kew Garden, United Kingdom. Later it was presented from Japan (Ishikawa, 1980), from the Korean Peninsula (Kontschán et al., 2014), from India (Datta and Bhattacharjee, 1989) and from Iran (Latifi et al., 2005). This species was collected in natural habitats only in East- and South-Asia and in the Middle-East. In Europe, this species was found only in greenhouses of botanical gardens.

\section{Key to the European species of the family Parholaspididae}

Notes: Karg (1993) listed seven species from Europe; three from them are known only from the European part of the former Soviet Union, but one species [Holaspina jogodinskyi (Alexandrov, 1963)] occurring close to river Volga is missing from it. Later Moraza and Peña (2006) added a new species to the European fauna, from Tenerife Island. Moraza and Peña (2006) also added a new subspecies (Gamasholapis gamasoides canariensis Moraza and Peña, 2006), but the differences between these original and newly described subspecies are very weak; therefore we did not place it into the key.

The Eastern border of Europe is the Ural Mountain; therefore we placed only these Russian species into the key, where the Europe or the East-European regions are mentioned in Petrova's (1977) key. 


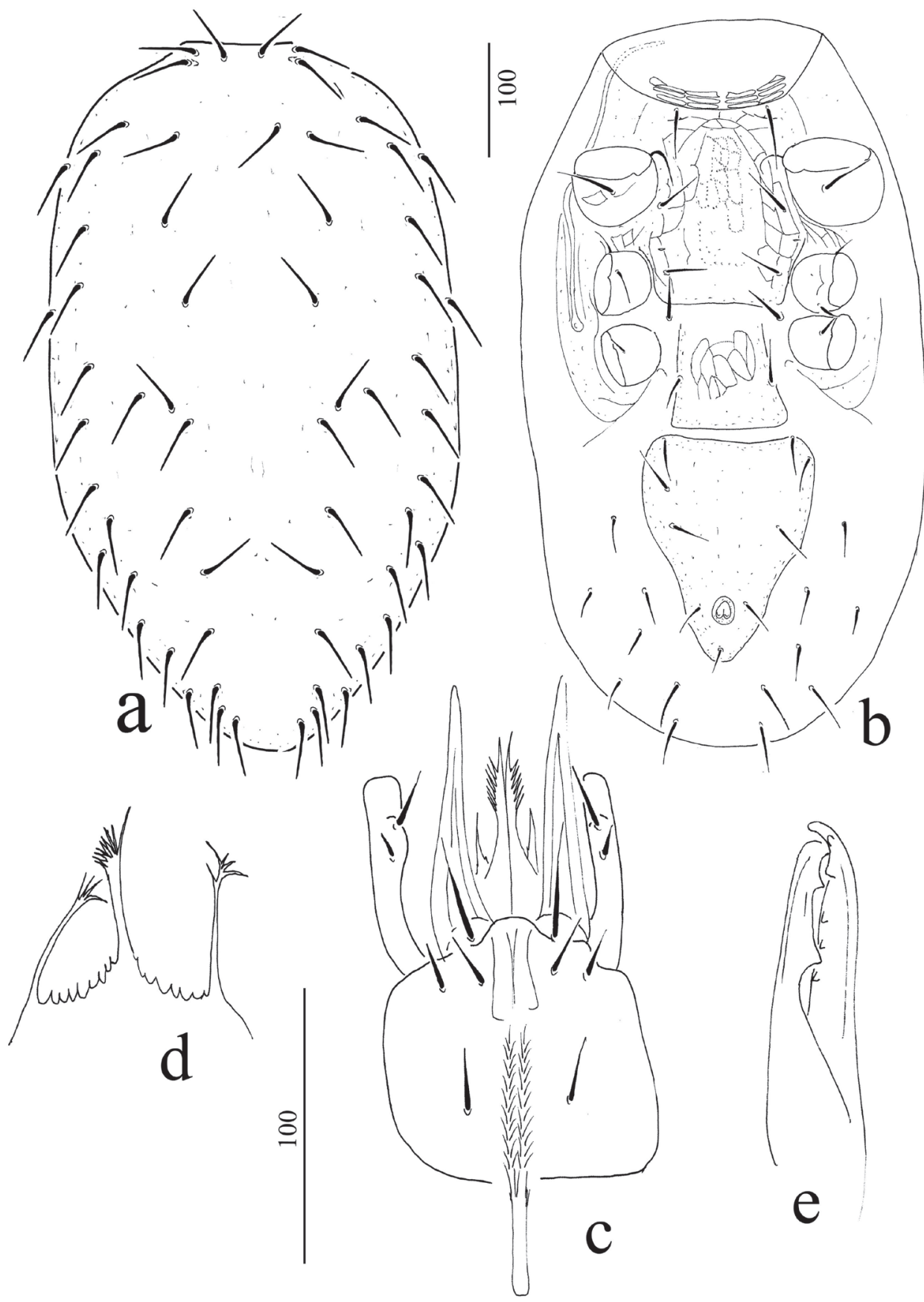

Fig. 1. Holaspina alstoni (Evans, 1956), female: a: dorsal shield, b: idosoma in ventral view, $\mathrm{c}$ : ventral view of gnathosoma, $\mathrm{d}$ : epistome, e: lateral view of chelicera 
1. Peritrematal shields fused with the ventrianal shield

- Ventrianal shield not fused with other ventral plates

2. Female genital shield posteriorly fused to ventrianal shield

Holaspulus tenuipes Berlese, 1904

- female genital shield not fused with the ventrianal shield 3

3. Sternal shield with reticulate sculptural pattern 4

- Sternal shield with a T-shaped groove and some oval pits. Neparholaspis arcuatus Petrova, 1977

4. Ventrianal shield very wide (width:length $=1: 0.54$ ), incision between fused peritrematal and ventrianal shield deep and curved caudally

. Neparholaspis cardioides Petrova, 1977

- Ventrianal shied narrower (width : length $=1: 0.74$ ), incision between fused peritrematal and ventrianal shield shallow and not curved

Neparholaspis unicus Petrova, 1967

5. Ventrianal shield with four pairs of ventral setae, majority of dorsal setae not needle-like Parholaspis kewensis Evans, 1956

- Ventrianal shield with three or four pairs of ventral setae, all dorsal setae smooth and needle-like 6

6. Ventrianal shield with four pairs ventral setae, anteriorly wide, distance between caudal margin of peritrematal shields and anteriolateral margin of ventrianal shield narrow, chelicerae short and robust

Gamasholapis gamasoides Berlese, 1904

- Ventrianal shield with three pairs of setae, narrow, distance between caudal margin of peritrematal shields and anteriolateral margin of ventrianal shield wide, chelicerae long and slender.

7. Ventrianal, sternal and genital shields with reticulate sculptural pattern forming punctuation; distal ventral seta in palp-trochanter not enlarged 8

- Ventrianal, sternal and genital shields without sculptural pattern; distal ventral seta in palp-trochanter enlarged

Holaspina canariensis Moraza and Peña, 2006

8. Setae $\mathrm{s} 1$ as long as setae $\mathrm{j} 1$, central branch of epistome peaked with one or more lateral spines

Holaspina alstoni (Evans, 1956)

- Setae s1 two times shorter than j1, central branch of epistome apically subdivided into two short and spine-like processes (Alexandrov, 1963)

Holaspina jagodinskyi

\section{Discussion}

This species was collected in natural habitats only in East- and South-Asia and in the Middle-East. In Europe, it was found only in greenhouses of botanical gardens; therefore the parholaspidid mites in Central Europe are surely introduced by human soil transport. The colonization of the natural habitats by the parholaspidid mites in Central Europe seems to be implausible, because the climate is probably not acceptable for these species; therefore they find suitable habitats only in the warm and wet greenhouses. Sim- 
ilarly to the other parholaspidid mites, H. alstoni is also a fast moving predatory mite like the native macrochelid, veigaiaid or parasitid mesostigmatans which can feed with other mites and springtails in the soil of greenhouses.

\section{Acknowledgement}

This study was supported by OTKA (NKFIH) 108663.

\section{Literature}

Boros, G. and Dózsa-Farkas, K. (2008): Marionina scintillans sp. n., a new enchytraeid species (Annelida: Oligochaeta) from Hungarian green houses. Acta Zool. Acad. Sci. Hung. 54, 113-123.

Datta, A. K. and Bhattacharjee, P. C. (1989): Krantzolaspina rebatii, a new genus and a new species (Acari: Mesostigmata: Parholaspididae) from Dibrugarh, Assam, India. In: G. P. Channabasavanna and C. A. Viraktamath (eds): Progress in Acarology, 1, Brill, Leiden, pp. 411-414.

Evans, G. O. (1956): On the classification of the family Macrochelidae with particular reference to the subfamily Parholaspinae (Acarina - Mesostigmata). P. Zool. Soc. London 127, 345-377.

Farrier, M. H. and Hennessey, M. K. (1996): Soil-inhabiting and free living Mesostigmata from North America. An annotated checklist with bibliography and index. North Carolina, Agricultural Research Service, North Carolina State University, Raleigh, North Carolina.

Ishikawa, K. (1980): Taxonomic and Ecological Studies in the Family Parholaspidae (Acari, Mesostigmata) from Japan. Bull. Nat. Sci. Mus. Ser. A (Zoology) 6, 1-25.

Johnston, D. E. (1969): Notes on types of Nearctic Acari in the Berlese collection. Parholaspididae (Parasitiformes-Mesostigmata). Redia 51, 269-275.

Karg, W. (1993): Acari (Acarina), Milben Parasitiformes (Anactinochaeta) Cohors Gamasina Leach. Raubmilben. Jena, Stuttgart, New York Gustav Fischer Verlag.

Kontschán, J. (2004): Magyarország faunájára új ászkarák (Reductoniscus constulatus Kesselyák, 1930 - Crustacea: Isopoda: Oniscidea) előkerülése az ELTE Füvészkertjéből (Budapest). (Reductoniscus costulatus Kesselyák, 1930, a new isopod species from Hungary). Fol. Mus. Hist. Nat. Matra 28, 89-90.

Kontschán, J., Park, S. J., Lim, J., Hwang, J. M. and Seo, H. Y. (2014): New Mesostigmata records and species from the Korean Peninsula. Opusc. Zool. Budapest 45, 17-23.

Korsós, Z., Hornung, E., Szlávecz, K. and Kontschán, J. (2002): Isopoda and Diplopoda of urban habitats: new data to the fauna of Budapest. Annls. hist-nat. Mus. natn. Hung. 94, 193-208.

Krantz, G. W. (1960): A re-evaluation of the Parholaspinae Evans 1956 (Mesostigmata: Macrochelidae). Acarologia 2, 393-433.

Kwon, Y. R. and Lee, S. Y. (1999): Soil microarthropod fauna in forest communities at the Gaya mountain national park. Korean J. Zool. 4, 33-39.

Latifi, M., Glida, H., Torabi, A. and Bertrand, M. (2005): Holaspina (syn. Parholaspulus) persicum, a new species of Parholaspididae from Iran (Acari: Mesostigmata). Acarologia 46, 189-194.

Lee, S. Y. and Lee, W-K. (1996): Three soil mites of the genus Holaspina (Parholaspididae: Mesostigmata) from Korea. Korean J. Zool. 1, 24-27.

Lee, W-K. and Lee, S. Y. (2000): Taxonomic study of Parholaspid mites (Acari: Mesostigmata) in Korea. Korean J. Syst. Zool. 16, 105-112.

Lindquist, E. E., Krantz, G. W. and Walter, D. E. (2009): Order Mesostigmata. In: G. W. Krantz and D. E. Walter (eds): A Manual of Acarology (Third ed.). Texas University Press, Lubbock, pp. 124-232.

Mahunka, S. and Mahunka-Papp, L. (2007): Contribution to the Hungarian Oribatida fauna (Acari) II. Opusc. Zool. Budapest 36, 69-77. 
Moraza, M. L. and Peña, M. A. (2006): Two new taxa of Parholaspidae Evans, 1956 (Acari, Mesostigmata) from Tenerife (Canary Islands). Graellsia 62, 75-86.

Petrova, A. D. (1977): Family Parholaspidae Evans, 1956. In: M. S. Ghilyarov and N. G. Bregetova (eds): Key to the Soil-Inhabiting Mites. Mesostigmata, Nauka, Leningrad, pp. 315-346. 